This PDF is a selection from an out-of-print volume from the National Bureau of Economic Research

Volume Title: The Regionalization of the World Economy

Volume Author/Editor: Jeffrey A. Frankel, editor

Volume Publisher: University of Chicago Press

Volume ISBN: 0-226-25995-1

Volume URL: http://www.nber.org/books/fran98-1

Publication Date: January 1998

Chapter Title: Why Do Countries Seek Regional Trade Agreements?

Chapter Author: John Whalley

Chapter URL: http://www.nber.org/chapters/c7820

Chapter pages in book: (p. $63-90)$ 


\title{
3 \\ Why Do Countries Seek Regional Trade Agreements?
}

\author{
John Whalley
}

\subsection{Introduction}

This paper argues that a wide range of considerations enter when countries seek to negotiate regional trade agreements. Some see trade agreements as providing underpinnings to strategic alliances, and hence implicitly form part of security arrangements (as in Europe). Smaller countries see trade agreements with larger partners as a way of obtaining more security for their access to larger country markets (as in the Canada-U.S. Free Trade Agreement [CUSTA]). Some countries have tried to use regional (and multilateral) agreements to help lock in domestic policy reform and make it more difficult to subsequently reverse (Mexico in North American Free Trade Agreement [NAFTA]). Other countries' use of regional trade agreements reflects tactical considerations; conscious efforts to use prior regional agreements to influence subsequent multilateral negotiation (services in CUSTA and in NAFTA). Regional trade arrangements around the world are thus different one from another, not the least because countries have different objectives when they negotiate them.

As a result, a wide range of differences have to be taken into account in analyzing them. Much of the recent literature on regionalism implicitly assumes that regional trade agreements are similar. This is partly because in analytical discussion it is common to analyze the symmetric case in which countries are of equal size (Krugman 1991; Haveman 1992; Krugman 1993). If any differentiation is noted, it is usually that some agreements (such as the Euro-

John Whalley is professor of economics at the University of Western Ontario and a research associate of the National Bureau of Economic Research.

The author is grateful to Jeff Frankel and participants both at the preconference meeting held in Cambridge, 19 July 1995, and at the conference in Woodstock for helpful comments. Later sections draw on joint work with Carlo Perroni. 
pean Union [EU]) are customs unions, while others (such as NAFTA) are free trade areas. Yet some are part of a process headed toward eventual deeper integration (European Community [EC] in the 1960s), some are consciously standalone, more shallow agreements (NAFTA), some are simple in structure while others are more complex, and these differences go well beyond differences between customs unions (CUs) and free trade areas (FTAs).

The line of argument offered is that these differences need to be factored into both an analysis of the effects of any given regional trade agreement, and any balanced discussion of the threat that regionalism now poses for the future evolution of the trading system. An implication is that the gain or loss to any country from a regional agreement needs to be evaluated relative to the appropriate counterfactual, which itself may be difficult to specify analytically. In this paper, I discuss how such considerations can change conventional analyses of the impacts of regional trade agreements, and summarize what is known about the significance of some of the factors involved in some specific cases.

\subsection{Recent and Longer-standing Regional Trade Agreements in the Trading System}

That regional trade agreements have been present in the multilateral trading system since its early days, and that they have grown in coverage and scope recently is hardly news. But the number and range of these agreements is now quite extraordinary.

Table 3.1 lists the regional trade agreements notified to General Agreement on Tariffs and Trade/World Trade Organization (GATT/WTO) and in operation as of 1 January 1995, and included in a recent WTO volume on regionalism.' This long list includes the formation of the European Free Trade Association, the bilateral arrangements between Canada and the United States under the Auto Pact of 1965 and the 1988 Canada-U.S. Free Trade Agreement; and other more recent initiatives including Community Association Agreements, Community Enlargement, NAFTA, Mercosur, the Australia-New Zealand Closer Economic Relationship (CER), and others.

Besides the more prominent regional arrangements involving the United States and the EC, an increasing number of these arrangements are between smaller countries. These usually attract less attention because the trade covered by them is relatively small. Earlier examples include the Latin American Free Trade Association of 1960, the Central American Common Market of 1960, and the (now defunct) East African Common Market of the same period. More recently, there have also been various bilateral agreements not notified to

1. Also see Stoeckel, Pearce, and Banks $(1990,24)$, for a detailed listing of various trading arrangements, as well as Schott (1989), appendix A, which lists all preferential trade agreements notified to GATT. Regional trade arrangements are also discussed in two recent volumes, one sponsored by GATT (Anderson and Blackhurst 1993), and the other by the World Bank (de Melo and Panagariya 1993). 
GATT/WTO; examples are the Chile-Mexico bilateral trade agreement concluded in 1991 and the 1992 Chile-Venezuela bilateral agreement. As well, there are wider-ranging agreements besides those in table 3.1; in the United Nations Conference on Trade and Development (UNCTAD), for instance, a negotiation on trade preferences among developing countries, the Generalized System of Trade Preferences (GSTP), is still ongoing, although not with any marked vigor. ${ }^{2}$

Thus, and as the chronology from Hamilton and Whalley (1996) shows (table 3.2), regional trade arrangements have been a central feature in the development and evolution of the postwar trading system rather than the exception, and this has been despite the growth in importance of GATT/WTO. Furthermore, as this chronology also clearly shows, the number of regional trade agreements has grown substantially in the trading system in the last few years. Most of the chronology is devoted to arrangements since 1991, with a wide range of bilateral and minilateral arrangements recently entering the system. Indeed, despite the presence of multilateral rules and disciplines in the system, it is still the case that most GATT/WTO contracting parties are now parties to at least one regional trade arrangement.

But these trade agreements, numerous as they are, also vary substantially one from another. These differences include the coverage of the agreements, the balance of concessions between the parties to the agreement, and whether the agreement forms part of an ongoing process of wider economic integration. Differences in coverage relate to such issues as whether or not freer factor flows are included (as in the EU), whether agreements seek to go beyond the coverage of GATT at the time (services in CUSTA; environment and labor standards in NAFTA); whether financial transfers are included; whether industrialization objectives (including production-sharing agreements) are included; and whether payments arrangements are a central feature of the agreement. And these all go beyond the widely noted differences between FTAs and CUs noted above.

De La Torre and Kelley (1992) list some of these differences for a sample of agreements between developing countries, reproduced here as table 3.3. While this table relates to only a subset of developing-country arrangements, the diversity among the agreements covered is immediately apparent. Some have provisions aiming to provide freer factor movements; some have payments arrangements, while others do not; some use a positive-list approach, in reaching agreed disciplines, and others a negative-list approach.

A similar range of differences can be found in regional arrangements among developed countries. For example, trade agreements in North America have special dispute-settlement procedures for anti-dumping and countervailing duties, trade provisions relating to the environment and labor standards, and com- 
1947 GATT agreed to by 23 countries, with article XXIV, which allows formation of CUs and FTAs under certain conditions.

1957 Treaty of Rome establishes the European Economic Community (EEC), a CU between Belgium, Luxembourg, France, the Netherlands, Germany, and Italy. Treaty in force 1 January 1958.

1959 Stockholm Convention establishes the European Free Trade Association (EFTA) in effect 1 July 1960. Members include Austria, Denmark, Norway, Portugal, Sweden, Switzerland, and the United Kingdom.

1960 Montevideo Treaty establishes Latin American Free Trade Association (LAFTA) comprising Brazil, Chile, Peru, Uruguay, Argentina, Mexico, and Paraguay.

Central American Common Market (CACM) formed; includes Costa Rica, El Salvador, Guatemala, Honduras, and Nicaragua.

1963 Yaoundé Convention between the EEC and former French, Belgian, and Italian colonies in Africa gives these countries preferential access to the EC and sets up the European Development Fund.

1965 Canada and the U.S. sign Automobile Products Trade Agreement (Auto Pact).

1969 Yaoundé Convention extended.

1973 EC enlarged to include Britain, Ireland, and Denmark.

1975 Yaoundé Convention superseded by Lomé Convention, extends preferential arrangements to include former colonies of Britain, and is widened to include countries in the Caribbean and Pacific.

1977 Association of Southeast Asian Nations (ASEAN) formed; includes Indonesia, Malaysia, Philippines, Singapore, and Thailand.

1981 Greece joins the EC.

1983 Australia and New Zealand form Closer Economic Relationship to provide for an FTA.

1984 U.S. implements Caribbean Basin Economic Recovery Act to extend duty-free treatment to 21 beneficiary countries in the region for 12 years.

1985 Israel-U.S. Free Trade Agreement enters into force. Over a 10-year period, all tariffs between the two countries to be eliminated.

1986 Portugal and Spain join the EC. Single European Act signed to provide for full European integration in 1992.

1989 Canada-U.S. Free Trade Agreement enters into force. Under agreement, by 1998 all items should be traded duty-free between the two countries.

1990 EC and EFTA undertake discussions on a European Economic Area (EEA) to provide for freer movement of goods, services, capital, and people between the two associations.

U.S. announces Enterprise for the Americas Initiative to explore a hemisphericwide free trade zone between countries of North, Central, and South America.

1991 U.S., Mexico, and Canada enter discussions on a North American FTA, leading eventually to the signing of NAFTA.

Andean Pact members (Bolivia, Colombia, Ecuador, Peru, and Venezuela) sign accord to implement free trade zone by the end of 1995.

Treaty of Asuncion signed by Brazil, Argentina, Uruguay, and Paraguay to form Mercosur (the South American Common Market). Aim is to create a duty-free common market by the end of 1994 . 
Chile and Mcxico sign free trade accord. All nontariff barriers to be eliminated. Common tariff of 10 percent to apply to 95 percent of trade as of January 1992. Tariff to be reduced to 0 over 4 years.

Turkey and EFTA sign a free trade agreement to go into force Janaury 1992. EFTA to eliminate duties on imports of industrial goods (excluding textiles) and processed farm products.

EC and EFTA finalize EEA to go into effect in 1993.

ASEAN Free Trade Agreement (AFTA) formed. Group agrees to 15-year period in which to create a single ASEAN market.

EFTA signs trade cooperation accords with Bulgaria, Romania, and three Baltic states.

EC signs association accords with Poland, Hungary, and Czechoslovakia. Agreements to result in free trade within 10 years.

1992 El Salvador, Guatemala, and Honduras agree to form a free trade zone. The countries agree to allow unrestricted movement of most goods and capital, and work toward establishing uniform tariffs on imports.

NAFTA (U.S.-Mexico-Canada) negotiations concluded. Agreement provides for the elimination of tariffs in stages over a period of no more than 15 years, and in 10 years in some cases, including a phase-out of tariffs on textiles and apparel. Side agreements later negotiated on labor and environment. The agreement goes into effect 1 January 1994.

Implementation of EEA (due to go into effect 1 January 1993) delayed when Switzerland voted against joining.

Poland, Hungary, Slovakia, and the Czech Republic establish a regional trade zone. Aim is to gradually eliminate tariffs over next 17 years and become more compatible with the EC and EFTA.

1993 Hungary and EFTA conclude a free trade agreement. Extends free trade in a range of goods, including processed agricultural goods, industrial goods, and fish.

Bulgaria and EFTA conclude free trade agreement. Extends free trade in industrial goods, processed farm goods, and fish products.

Chile and Venezuela sign a free trade agreement. Import tariffs expected to be eliminated on 90 percent of products by 1997 .

Chile and Bolivia sign a bilateral agreement to reduce tariffs.

South Asian Preferential Trading Agreement established with the aim of forming a common market between Bangladesh, Bhutan, India, Maldives, Nepal, Pakistan, and Sri Lanka.

Nicaragua, Honduras, El Salvador, and Guatemala reach an agreement to liberalize trade. Barriers to trade in textiles, shoes, and leather goods will be reduced.

Group of Three (Mexico, Venezuela, and Colombia) sign a free trade agreement to go into effect June 1994. Agreement covers market access, rules of origin, investment, government procurement, and intellectual property.

Chile and Colombia sign a free trade agreement. Most nontariff barriers eliminated and tariffs reduced.

Guatemala, Honduras, El Salvador, Nicaragua, Costa Rica, and Panama sign an agreement toward freer trade and increased integration.

Turkey and the EC negotiate a timetable leading to CU between Turkey and the EC by 1995 . 
Table 3.2

(continued)

1994 EEA comes into effect, creating an FTA between the EU (EC) and the EFTA countries of Austria, Finland, Norway, Sweden, and Iceland.

Sweden, Finland, Austria, and Norway negotiate full membership in the EU.

Mexico and Costa Rica conclude a free trade agreement to go into effect January 1995. Tariffs and most nontariff barriers to be eliminated. Provisions included on national treatment for investment, intellectual property rights, labor mobility, and dispute settlement.

Andean Pact members agree to a common external tariff. Four-tier tariff to go into effect January 1995.

Colombia and Caricom conclude a free trade agreement to go into effect January 1995. Colombia to gradually reduce tariffs on Caricom products over 3-year period; Caricom to take 5 years.

Mercosur members reach a compromise agreement on a common tariff structure allowing CUs to become effective January 1995.

APEC members agree to accelerate the liberalization of trade and investment measures within the group. Members will begin liberalizing tariff and other barriers in 2000 and developed-country members will achieve an open market by 2010 . The developing countries will have until 2020 to complete their liberalization. APEC consists of Australia, Brunei Darussalam, Canada, Chile, Hong Kong, Indonesia, Japan, Malaysia, Mexico, New Zealand, Papua New Guinea, People's Republic of China, Philippines, Singapore, S. Korea, Taiwan, Thailand, and U.S.

Chile formally invited to begin negotiations to join NAFTA. At the Summit of the Americas held in Miami (9-11 December) the 34 countries located in North, Central, and South America, and the Caribbean jointly agree to negotiate an FTA of the Americas by the year 2005.

1995 The EU and Turkey agree on a CU accord. Tariffs will be eliminated and a common tariff established on products from outside the CU. Some EU agriculture restrictions will still apply to Turkish exports. The $\mathrm{CU}$ goes into effect 1 January 1996.

Chile begins negotiating with the members of NAFTA (Mexico, Canada, and the U.S.). Negotiations are expected to be completed by end of 1995 .

Estonia, Lithuania, and Latvia sign association agreements with the EU. The agreements provide trade and cooperation deals and possible future EU membership.

Vietnam joins ASEAN and is given longer implementation periods to fulfill ASEAN liberalization timetables.

Source: Hamilton and Whalley 1996, table 6.1.

plex sectoral arrangements in autos and textiles; while European arrangements instead have much more extensive sectoral arrangements in agriculture and steel, interregional resource transfers through social and regional funds, free labor mobility provisions, and other provisions not found in North American trade agreements.

It is also clear that these regional agreements embody much more than discriminatory trade-barrier reduction as it is common to represent them in the 
Table 3.3

Differences among Selected Regional Trade Arrangements between Developing Countries

\begin{tabular}{|c|c|c|c|c|c|c|c|}
\hline & CACM & ASEAN & $\begin{array}{l}\text { LAFTA/ } \\
\text { LAIA }\end{array}$ & $\begin{array}{c}\text { Andean } \\
\text { Pact }\end{array}$ & ECOWAS & PTA & $\mathrm{GCC}$ \\
\hline Tariff elimination & 0 & 0 & 0 & 0 & 0 & 0 & 0 \\
\hline Nontariff elimination & 0 & 0 & & 0 & 0 & 0 & \\
\hline Positive list & & 0 & & & 0 & 0 & \\
\hline Negative list & & & & 0 & & & \\
\hline Rules of origin & & 0 & & & 0 & 0 & 0 \\
\hline Common external tariff & 0 & & & 0 & 0 & & 0 \\
\hline $\begin{array}{l}\text { Special timetable for } \\
\text { liberalization }\end{array}$ & 0 & & & 0 & 0 & 0 & 0 \\
\hline Free trade in services & & & & & & & 0 \\
\hline Free movement of labor & & & & & 0 & & 0 \\
\hline Free movement of capital & & & & & 0 & 0 & 0 \\
\hline Promotion of industrialization & 0 & 0 & 0 & 0 & 0 & 0 & 0 \\
\hline Compensation fund & & & & & 0 & 0 & 0 \\
\hline $\begin{array}{l}\text { Promotion of other trade } \\
\text { objectives }\end{array}$ & & 0 & & 0 & 0 & & \\
\hline $\begin{array}{l}\text { Accompanying payments } \\
\text { arrangement }\end{array}$ & 0 & & 0 & & 0 & & \\
\hline
\end{tabular}

Source: De La Torre and Kelley 1992.

Notes: CACM denotes the Central American Common Market; ASEAN, the Association of Southeast Asian Nations; LAFTA/LAIA, Latin American Free Trade Area; ECOWAS, the Economic Community of west African States; PTA, the Preferential Trade Agreement in Eastern and South Africa; and GCC, the Gulf Cooperation Council.

literature, whether in explicit tariff form or in the form of ad valorem equivalents. Factor mobility as well as goods mobility is involved to some degree in more agreements. Moves toward harmonized regulatory arrangements are at issue in financial services, transportation, and other service sectors. And in moving ahead of the GATT/WTO into such areas as environment and labor standards, agreements such as NAFTA have moved into areas where there is an explicit linkage drawn between trade and nontrade objectives, with trade policy potentially becoming the policeman to be used to achieve nontrade objectives. The diversity in regional arrangements therefore also implies that analyzing them simply as preferential reductions in ad valorem equivalent trade barriers can be potentially misleading.

\subsection{Country Objectives Underlying Regional Trade Agreements}

These differences in content and form among regional trade agreements, in large part, reflect sharp differences in the objectives of the countries seeking them. Hence the rationale for the paper: why do countries seek regional trade agreements?

In some cases, there are multiple country negotiating objectives that drive 
participation in regional trade agreements; in other cases, one or two objectives tend to be dominant. It is also the case that objectives frequently reflect only the interests of narrower subgroups within countries, rather than a wider country interest, as with sectoral arrangements in textiles, agriculture, autos, or other areas perceived to be politically sensitive. Nonetheless, once the reasons that countries seek these arrangements are understood, the form that the eventual agreement takes becomes more explicable.

\subsubsection{Traditional Trade Gains}

Perhaps the most conventional objective thought to underlie a country's participation in any trade negotiation is the idea that through reciprocal exchanges of concessions on trade barriers there will be improvements in market access from which all parties to the negotiation will benefit. The reasons for participating in a regional negotiation rather than any other type, including multilateral, are usually that key trading partners are involved, that the chances of success are seen as high because the number of countries is small, or there has been a prior history of frustration with negotiating failures at the multilateral level. ${ }^{3}$ In reality, however, and as is well known from the research literature on regional trade arrangements, gains may not accrue to countries forming a $\mathrm{CU}$ since trade may also be diverted to higher-cost suppliers within the integrating area (Viner 1950); that is, trade-diversion losses may outweigh trade-creating gains.

Despite this, this idea of trade gains from regional integration was the key economic objectives behind the creation of the EC in the late 1950s, although probably not the central objective, which, as discussed below, was strategic. The notion that gains follow from increased regional trade has also motivated much of the postwar support for other regional trade agreements, which has in turn stimulated extensive literature on the effects of CUs and FTAs.

\subsubsection{Strengthening Domestic Policy Reform}

Yet another objective countries have in seeking regional trade agreements is the idea that a regional trade treaty can underpin domestic policy reform and make it more secure; that is, by binding the country to the masthead of an international trade treaty, any future reversal of domestic policy reform becomes more difficult to implement.

In reality, this can be an objective in either bilateral or multilateral negotiation and need not be an objective solely for regional trade agreements. However, this was a central preoccupation behind the Mexican negotiating position on NAFTA. As such, it led to the outcome that Mexican negotiators were less concerned to secure an exchange of concessions between them and their nego-

3. These were all key factors in Canada's decision to pursue bilateral negotiations with the United States in the mid-1980s, but prior to this the argument had been that the security of multilateral disciplines were needed around any bilateral arrangement with such a dominant trading partner to ensure the enforcement. 
tiating partners, and were more concerned to make unilateral concessions to larger negotiating partners with whom they had little negotiating leverage as part of the bilateral negotiation. The idea was clearly to help lock in domestic policy reform through this process.

Pursuit of this objective by one of the parties to a negotiation, however, makes it likely that the concessions made by the parties in the negotiation are asymmetric (as was the case in the NAFTA negotiation and in the Canada-U.S. negotiations). ${ }^{4}$ The relative size of the countries involved in both of the North American negotiations meant that the negotiating outcome was one-sided, especially in the NAFTA negotiation, since one of the parties was, in effect, using a negotiation on a regional trade agreement for nontrade purposes.

\subsubsection{Increased Multilateral Bargaining Power}

A further objective for countries that adopt regional trade agreements is to increase their bargaining power with third countries by negotiating an agreement with common external barriers (i.e., through a $\mathrm{CU}$ rather than a FTA). This idea was shared by the countries involved in the formation of the $\mathrm{EC}$ in the late 1950s. At the time, the notion was that individually European countries might have limited leverage in a negotiation with the United States, including multilaterally, but if all the European countries acted cooperatively in using a common trade policy, they would increase their leverage.

Indeed, one argument sometimes heard is that it was the creation of the EC that propelled GATT negotiations, first in the Dillon Round (1959-61), then in the Kennedy Round (1963-67), and subsequently in the Tokyo Round (1973-79). These rounds were initiated by the United States, who sought to deal with issues of access to a unified European market with individual European countries adopting common external (third-country) barriers. This objective of increasing negotiating power has also been present in some of the Latin American arrangements (such as Mercosur) where the argument has been that groups of countries will have more leverage in accession negotiations to NAFTA than will individual countries. Similar arguments were also made in Eastern Europe after 1989, where it was argued that a prior regional negotiation between Hungary, Poland, and Czechoslovakia (as it then was) would give increased combined leverage to these countries in EC accession negotiations.

\subsubsection{Guarantees of Access}

An objective present in recent large-small country trade negotiations, beginning with the Canada-U.S. agreement, is to use a regional trade agreement to make access to the larger country market in the region more secure for the smaller country. In the Canada-U.S. case, the Canadian aim was to achieve a regional trade agreement that gave Canadians some degree of exemption from the use of anti-dumping and countervailing duties by the U.S. producers. They 
also sought special bilateral arrangements that would limit the application of U.S. safeguard measures to Canada (a form of escape from most-favored nation $[\mathrm{MFN}])$.

These arrangements were secured by implicit side payments in the form of domestic policy disciplines undertaken by Canada and favorable to the United States. Special bilateral policy disciplines were agreed to as part of the trade agreement on energy and investment policies, which effectively prevented the return in Canada to older policies adverse to the United States under the Canadian Energy Policy and the former Canadian Foreign Investment Review Agency. Canada also made changes in pharmaceutical protection laws parallel to the trade agreement, and limited special Canadian protection for wine and beer. This idea of achieving access guarantee objectives for the smaller country in a regional trade agreement was also there in the Mexican case, with investment and energy provisions in the agreement, different from but related to those present in the Canadian case; although this was probably a less significant objective than that of underpinning domestic policy reform.

\subsubsection{Strategic Linkage}

A further country objective in negotiating regional trade agreements is that such agreements can help underpin security arrangements among the integrating countries, a central theme in early European integration in the 1950s. The idea was that a postwar regional trade agreement that produced enhanced trade flows between Germany and France would help prevent a fresh outbreak of European war, especially in light of Franco-Prussian relations between 1870 and 1945. As such, strategic linkage (helping prevent further European war) became the dominant consideration in the negotiation of European trade arrangements, overriding all other integration objectives because the issues at stake were so important.

This is also a key difference between European and recent North American trade agreements, in that strategic linkage is largely missing as a country objective in the latter group of regional arrangements. European integration has been able to move progressively toward ever deeper integration, because the political commitment to it is so strong, almost to the point of agreement to found a European federation to partially supersede arrangements between the individual nation-states in Europe. This is reflected in the fact that European integration provides for both an ongoing process of integration and an institutional framework to support ever deeper integration, including a European court structure. More recent North American economic integration, as reflected in NAFTA, stands, in contrast, as a series of one-off agreements, and provides no road map for ongoing and more extensive integration.

\subsubsection{Multilateral and Regional Interplay}

A final set of objectives that enters into country calculations of whether and or how to negotiate regional trade agreements involves the actual or potential 
use of regional agreements for tactical purposes by countries seeking to achieve their multilateral negotiating objectives. The opposite can also be true in that ongoing multilateral negotiations can be used to influence the outcome of regional negotiations, since multilateral negotiations create regional opportunities.

Hence, during the Uruguay Round, it was widely thought that it was to the U.S. advantage to have regional trade negotiations under way, so that in dealing with recalcitrant multilateral negotiating partners, the United States could threaten or actually play the bilateral card, and engage in active discussions with prospective regional partners. If multilateral partners were slow to react, initiation of regional negotiations would be the result.

In turn, it was also widely believed during the round that smaller countries consciously used multilateral and regional interplay as a way of improving their negotiating leverage in regional arrangements with the larger countries. Hence, Canada consciously offered the United States the possibility of negotiating regional arrangements in services, which was then an emerging issue in multilateral negotiation, with the idea that a prior regional agreement would give the United States more leverage in subsequently multilateralizing their preferred services agreement. The Canadian hope was that this could then enable Canada to obtain improvements elsewhere in the package of issues making up the regional agreement. In the Canada-U.S. negotiation (with the outcome also echoed in NAFTA), tactical interplay between regional and multilateral trade negotiations also provided a reason for a number of seemingly largely contentless chapters in the final agreement. These were offered for multilateral agenda-shaping purposes by the smaller country, and helping establish them in this way on the agenda for future multilateral negotiations was one of the benefits to the larger country.

\subsection{Assessing the Importance of Country Objectives in Regional Trade Negotiations}

Assessing the relative importance of the various objectives set for regional trade agreements by individual countries is difficult, since the quantitative orders of magnitude are often hard to pin down. They also clearly vary in importance from agreement to agreement, and from country to country. Table 3.4 sets out a schematic representation illustrating the importance of various objectives for particular agreements, denoting them as strong or weak objectives. This table largely summarizes the discussion in the earlier section but usefully illustrates the diversity in objectives involved.

To go beyond this, however, quantitative work is needed even if it is only to provide an assessment of the relative importance of some of these objectives. A calibrated general equilibrium model of world trade and protection, on which I have recently worked jointly with Carlo Perroni (Perroni and Whalley 1994) provides some insights as to the considerations involved in a number of these cases, indicating where large or small effects are at stake, and offering an as- 
Table 3.4

Assessing the Importance of Country Objectives for Particular Regional Agreements

\begin{tabular}{|c|c|c|c|c|}
\hline \multirow[b]{2}{*}{ Country Objectives } & \multicolumn{4}{|c|}{ Regional Trade Agreement } \\
\hline & $\mathrm{EC}$ & NAFTA & Canada-U.S. & Mercosur \\
\hline Traditional trade gains & W & & & W \\
\hline $\begin{array}{l}\text { Strengthening domestic } \\
\text { policy reform }\end{array}$ & & $\begin{array}{c}S \\
\text { (Mexico) }\end{array}$ & & \\
\hline $\begin{array}{l}\text { Increased multilateral } \\
\text { bargaining power }\end{array}$ & W & & & $\begin{array}{c}\text { W } \\
\text { (Bargaining power } \\
\text { in NAFTA) }\end{array}$ \\
\hline Access guarantees & & w & $\begin{array}{c}\mathrm{S} \\
\text { (Canada) }\end{array}$ & \\
\hline Strategic linkage & $S$ & & & \\
\hline $\begin{array}{l}\text { Multilateral and regional } \\
\text { interplay }\end{array}$ & & $\begin{array}{c}\mathrm{W} \\
\text { (U.S.) }\end{array}$ & $\begin{array}{c}\text { W } \\
\text { (Canada, U.S.) }\end{array}$ & $S$ \\
\hline
\end{tabular}

Notes: $S=$ strong objective; $W=$ weaker objectives.

sessment of the net effect, when two partially offsetting considerations are involved. These include the relative importance of access security versus tradegain objectives for regional trade agreements, tactical considerations between regional and multilateral trade agreements, and sequencing issues as to who one negotiates with first, and other considerations.

This model has primarily been used to analyze the implications of recent regional arrangements between small and large countries, and principally the Canada-U.S. agreement, using an enlarged version of the Nash retaliatory tariff and trade structure first used by Johnson (1953-54), and Gorman (1957), and subsequently expanded on in Hamilton and Whalley (1983), Markusen and Wigle (1989), Kennan and Riezman (1990), and elsewhere. In the process, Perroni and I have been able to compute Nash equilibria in tariff rates in higher dimensional space than previous literature, with a more complex analytical structure and without the restriction to constant-elasticity, excess-demand forms used in some of the earlier literature.

The Perroni-Whalley model incorporates seven regions (United States, Canada, Mexico, Japan, the EC, other Western Europe [OWE], and a residual restof-the-world [ROW]) allowing it to capture some of the key regional trading arrangements currently operating in the global economy. It is calibrated to 1986 regional production, consumption, and interregion trade-flow data, and to literature-based trade elasticity estimates. Because of the large dimensionalities involved in computing Nash equilibria in the presence of multiple goods and regions, it is restricted to one produced good for each region-with importables in each region treated as qualitatively different across sources of supply (by exporting country). Preferences in each region are defined over the own good, and a composite of importables; with substitution among the import sources entering as part of the definition of the composite. This specification, 
in effect, amounts to a pure exchange economy, where trade offer curves are fully determined by endowments and preferences.

The model incorporates regional trade arrangements not only as barrier reductions, but also as mutually agreed constraints on retaliation. In the event that retaliation breaks out between regions in the model, regional trade agreements are assumed to hold. Using the model, if no retaliation is considered, incremental gains or losses to regions from any given agreement can be computed in the conventional way using the status quo as the reference point, assessing the incremental effects of regional barrier reductions. But relative to an unconstrained trade war, the introduction of such constraints produces a different set of gains and losses for the countries involved. ${ }^{5}$ Smaller countries gain substantially, while larger countries suffer from the restraints on their retaliatory power.

Indeed, compensation in the form of other nontrade concessions by smaller to larger regions may be required for an agreement to proceed. Perroni and Whalley estimate the side payments involved using a two-stage game structure as described in Riezman (1985). In the first stage of this game, countries form coalitions; in the second stage of the game, Nash tariffs are determined. Riezman's framework, however, is extended by allowing for side payments within coalitions, and by introducing uncertainty in the first-stage bargaining game.

Nash tariff equilibria, whether constrained or unconstrained, are computed in the model by sequentially determining optimal tariff rates for each region, holding the other region's tariff rates constant. Each calculation in the sequence involves the computation of a global competitive equilibrium, with a search across the relevant equilibria for that which gives maximum regional utility. A lengthy computational procedure is thus involved. ${ }^{6}$

In this, all regions are assumed to play strategically in their tariff setting, with the exception of the ROW, which offers no strategic response. This assumption reflects the observation that trade policies in a large number of countries belonging to the ROW bloc are, in reality, not coordinated in any meaningful way, implying that the strategic power of each individual country in the ROW is negligible. ${ }^{7}$ In the central-case version of the model, the objective of the tariff-setting authority in each region is welfare maximization for its representative consumer. For CUs, the tariff-setting authority is assumed to maximize a linear combination of the welfare levels of the representative consumers of its member countries, where the weights are proportional to benchmark GNP levels. ${ }^{8}$

5. The risk to smaller countries, in reality, is that their largest trading partner (the United States for Canada) may turn protectionist, more than the outbreak of a full global trade war.

6. The GAMS/MINOS (General Algebraic Modeling System) numerical optimization software (Brooke, Kendrick, and Meeraus 1988) is used.

7. This assumption is clearly a little strong, as the ROW includes a number of larger countries such as China, India, and Brazil, although their individual shares in total world trade are small.

8. Gatsios and Karp (1991) show that it may be optimal for smaller countries to fully delegate tariff setting to larger countries in a CU. 
In those cases where two or more regions form an FTA or a CU, model computation of Nash equilibria takes place in the presence of additional constraints on each region's optimization problem. Regions within an FTA have tariffs on bilateral trade frozen at zero. For CUs, external barriers are identical for all members of the union, in addition to freezing bilateral tariffs. For simplicity, Perroni and Whalley also require that import duties set by all other regions against members of the union are uniform across exports originating from all members of the union. ${ }^{9}$

Model parameters are calibrated to 1986 output, trade flows, and protection data by region using the procedures described in Mansur and Whalley (1984). On the basis of surveyed elasticity studies supplemented by information on relative country size, a central case configuration of price and income elasticities is adopted. Perroni and Whalley perform sensitivity analyses around these by varying elasticities values, limited by the number of potential combinations of elasticity configurations that can be considered. ${ }^{10}$

The model described above has been used by Perroni and Whalley to compute a number of counterfactual equilibria to analyze the impact of regional trade agreements. These include Nash (postretaliation) equilibria where trade wars are unconstrained; cases where countries entering into an FTA or CU agree not to retaliate against each other; cases where trade wars occur with differing regional groupings; and, for the sake of comparison, cases where no trade wars occur, but regional agreements are implemented. As noted above, in all cases, the assumption is made that the ROW uses no retaliatory tariffs. This implies that retaliation is limited to six of the seven regions in the model.

Table 3.5 reports welfare results for a variety of regional trade agreements that constrain retaliation, with results for an unconstrained Nash tariff war reported in the first column. In the presence of a CUSTA, in which Canadian and U.S. tariffs remain bilaterally at zero, even in a trade war, large benefits accrue to Canada. This is because of both continued and preferential access to U.S. markets, which is ever more valuable as U.S. tariffs against other regions rise. Relative to an unconstrained trade war, shown in the first column of table 3.5 , gains to the United States are converted to a loss, and the previous large loss to Canada is now converted to a small gain. This small gain reflects not only continued access to the U.S. market, but also the added feature that this access is preferential. As barriers rise progressively in the U.S. markets against other

9. They also assume that the ROW, which does not set its tariffs strategically, also conforms to this rule.

10. In model results, postretaliation Nash tariffs are directly related to import demand elasticities (hence, to export supply elasticities), with tariff levels increasing sharply as import demand elasticities approach unity (in absolute value). With the Armington treatment in preferences, two levels of substitution are involved: one between imports as a composite and domestically produced goods (which in the model is determined by import demand elasticities) and the other between imports of different origin (which in the model is determined by export demand elasticities). These two separate elasticities jointly determine import demand elasticities by import type with region and, at the same time, export supply elasticities in all regions. 


\begin{tabular}{|c|c|c|c|c|c|c|c|}
\hline Region & $\begin{array}{l}\text { Unconstrained } \\
\text { Trade } \mathrm{War}^{\mathrm{a}}\end{array}$ & $\begin{array}{l}\text { Canada- } \\
\text { U.S. FTA }\end{array}$ & $\begin{array}{l}\text { Canada- } \\
\text { U.S. CU }\end{array}$ & $\begin{array}{c}\text { North } \\
\text { American } \\
\text { FTA }^{\mathrm{b}}\end{array}$ & $\begin{array}{c}\text { North } \\
\text { American } \\
\mathrm{CU}^{\mathrm{c}}\end{array}$ & $\begin{array}{l}\text { Simultaneous } \\
\text { North } \\
\text { American } \\
\text { and European } \\
\text { FTA }^{\mathrm{b}}\end{array}$ & $\begin{array}{l}\text { Simultaneous } \\
\text { North } \\
\text { American } \\
\text { and European } \\
\text { CU }\end{array}$ \\
\hline \multicolumn{8}{|c|}{ Hicksian Equivalent Variations (billions of U.S. dollars) } \\
\hline U.S. & +52.5 & -9.5 & +22.1 & -15.3 & +18.6 & -4.5 & +19.6 \\
\hline Canada & -100.2 & +5.1 & +3.4 & +1.2 & +1.5 & +13.6 & -2.9 \\
\hline Mexico & -32.1 & -19.9 & -32.2 & -0.3 & +0.5 & +4.6 & -1.2 \\
\hline Japan & -73.9 & -33.8 & -73.7 & -28.7 & -73.6 & -17.4 & -76.7 \\
\hline $\mathrm{EC}$ & +128.4 & +142.0 & +119.4 & +145.3 & +116.6 & +38.7 & +87.3 \\
\hline OWE & -131.7 & -119.7 & -135.5 & -118.1 & -137.0 & +42.3 & +41.5 \\
\hline ROW & -1051.0 & -879.1 & -1082.5 & -857.9 & -1101.9 & -461.7 & -1330.0 \\
\hline World & -1208.1 & -914.8 & -1179.0 & -873.9 & -1175.2 & -384.4 & -1262.3 \\
\hline \multicolumn{8}{|c|}{ Hicksian Equivalent Variations as a Percent of National Income } \\
\hline Canada & -25.5 & +1.3 & +0.9 & +0.3 & +0.4 & +3.5 & -0.7 \\
\hline Mexico & -8.5 & -5.2 & -8.5 & -0.07 & +0.1 & +1.2 & -0.3 \\
\hline Japan & -5.2 & -2.4 & -5.2 & -2.0 & -5.2 & -1.2 & -5.4 \\
\hline $\mathrm{EC}$ & +3.7 & +4.1 & +3.4 & +4.2 & +3.4 & +1.1 & +2.5 \\
\hline OWE & -32.2 & -29.2 & -33.1 & -28.9 & -33.5 & +10.3 & +10.1 \\
\hline ROW & -10.6 & -8.8 & -10.9 & -8.6 & -11.1 & -4.6 & -13.4 \\
\hline World & -6.0 & -4.5 & -5.8 & -4.3 & -5.8 & -1.9 & -6.2 \\
\hline
\end{tabular}

Source: Perroni and Whalley 1994.

anconstrained trade war involves all regions except ROW adopting optimal bilateral tariffs against each and all trading partners.

'In an FTA, tariffs are bilaterally zero among member countries, and remain so throughout any retaliatory trade war.

In a CU, tarrifs are bilaterally zero among member countries, remaining so throughout any retaliatory trade war, and a common external tariff is set strategically by the union against third countries.

'North America is United States, Canada, and Mexico; European implies EC plus OWE. 
suppliers from Japan, the EC, and elsewhere, the value of trade preferences to Canada become progressively larger. Gains to the EC are higher in the event of a Canada-U.S. FTA than in the unconstrained trade war case, because a free trade agreement constrains retaliation by the United States, owing to the significantly lowered tariff that Canada applies to third-country markets in the event of a global trade war between Canada and the United States. This result is reversed if the United States and Canada form a CU rather than an FTA, since their retaliatory power against the EC is now enhanced (third column of table 3.5). In the CU case, bilateral tariffs are zero as in an FTA, but a common external tariff applies against third countries. A surprisingly large difference occurs in results for the United States with this change. There are significant benefits to the United States and reduced benefits to Canada. Positive benefits for the United States reflect the feature that, with a common external tariff, the United States can now induce Canada to follow a higher tariff, against third countries along with the United States. As a result, and as results in table 3.5 indicate, gains to the EC in a trade war are reduced. These results clearly suggest that a bilateral trade agreement between Canada and the United States would not occur were it not also accompanied by side payments, since it would represent a losing proposition for the United States compared to a full Nash equilibrium, while it would be a strongly gaining proposition for Canada. The form of Canada-U.S. regional agreement that has emerged as essentially safehaven driven with side payments is thus consistent with these country objectives.

North American trilateral arrangements have similar effects to those of the bilateral Canadian and Mexican agreements, except that now the benefits of access are shared by Canada and Mexico, and benefits to the United States are lowered. Under a trade war in the presence of a North American FTA, the United States loses rather than gains as it would with a CU. Also, the United States gains less with a three-way CU than it would in a two-way union with either Canada or Mexico.

Welfare effects of simultaneous bloc enlargements occurring in Europe and in North America are reported in the final two columns of table 3.5. ${ }^{\text {I }}$ The gains to the EC and the United States are significantly lower than in a full unconstrained trade war, the more so with FTAs than with regional CUs. The biggest loser is the ROW bloc, which loses even more than in the unconstrained case. Also, a trade war with the simultaneous formation of a North American and a European CU produces a larger negative aggregate welfare effect than an unconstrained trade war. ${ }^{12}$

Perroni and Whalley also report the welfare effects of alternative regional

11. The European trade arrangements considered here are more comprehensive than the current EC EFTA agreement, since the OWE bloc includes countries that do not belong to EFTA.

12. Kennan and Riezman (1990) also show that the formation of a CU in a strategic tariff setting has ambiguous welfare effects, whereas the formation of an FTA unambiguously improves world welfare. 
arrangements in the absence of any strategic tariff setting. Generally speaking, the effects are small relative to a trade war. In most cases, participants in the regional arrangements all benefit, the more so with CUs than with FTAs. In a few cases where regional participants lose, this is a reflection of elasticity parameters and asymmetric initial protection levels. For the purpose of the discussion here, however, the small size of these welfare effects from regional agreements emphasizes the dominance of access guarantee objectives for these agreements from a smaller-country point of view over conventional barrier reduction.

Perroni and Whalley also provide details as to the model outcome of a Nash tariff war with no prior regional agreement constraining retaliation. Postretaliation Nash tariffs are extremely high, and the more so the larger the country. These results correspond with the widespread intuition that an all-out global trade war would be extremely destructive of trade, and yield large shocks to individual economies. Thus, in the case of the EC, tariffs in the range of 900 to 1000 percent are generated by the model, with rates around 500 percent in the case of the United States, ${ }^{13}$ the difference between these two reffecting the relative importance of trade to GDP in these countries. Smaller estimates are obtained for Mexico and Canada, which have less retaliatory power than the EC, and the United States, and Japan. These high postretaliation tariffs are in part a reflection of the elasticity values used in the central case specification of the model, ${ }^{14}$ which, while literature-based, are still on the low side. Associated impacts on trade flows in the Nash tariff equilibrium show large reductions in particular bilateral trade linkages, such as between Canada, and the United States, where high retaliatory tariffs occur in the larger country.

Results also suggest that large countries benefit substantially from unconstrained retaliation. Large countries thus have more strategic leverage than small countries in regional trade negotiations, and small countries experience sharp reductions in bilateral trade flows with their largest trading partners (Canada, Mexico with the United States, and OWE with the EC). Thus, smaller countries lose from an all-out trade war, and in the case of Canada and OWE, these losses are large, in the region of 25 percent of national income.

These results thus underscore the proposition that it is the threat of global trade war in which small countries are excluded from access to large-country markets that propels the smaller countries into regional trade negotiations with the larger countries. In other words, on quantitative grounds it is sensible that a key objective of smaller countries in regional negotiations should be the qual-

13. In some cases such high tariff ratcs cffectively amount to prohibitive import barriers, resulting in reductions in trade flows of almost 100 percent, although, with internationally differentiated products in the model trade, flows never becomes zero.

14. The U.S.-Canada Nash tariffs computed by Markusen and Wigle (1989) are much smaller then the ones here. This model, however, is calibrated to demand and supply clasticitics, and not directly to literature estimates of trade clasticities. 
Table 3.6

Perroni and Whalley's Estimates of the Welfare Effects of Sequential Entry into North American Regional Trade Agreement, Central Case Elasticity Model $\left(\pi_{w}=0.5, \rho=1.3\right)$

\begin{tabular}{lccc}
\hline & \multicolumn{3}{c}{ Expected Utilities } \\
\cline { 3 - 4 } Sequence & U.S. & Canada & Mexico \\
\hline Free trade area & & & \\
U.S.-Canada, U.S.-Canada-Mexico & 1.015 & 0.883 & 0.977 \\
U.S.-Mexico, U.S.-Canada-Mexico & 1.013 & 0.889 & 0.987 \\
U.S.-Canada-Mexico & 1.014 & 0.873 & 0.994 \\
Customs unions & & & \\
U.S.-Canada, U.S.-Canada-Mexico & 1.018 & 0.917 & 0.971 \\
U.S.-Mexico, U.S.-Canada-Mexico & 1.017 & 0.872 & 1.018 \\
U.S.-Canada-Mexico & 1.016 & 0.894 & 1.009 \\
\hline
\end{tabular}

Source: Perroni and Whalley 1994.

Notes: $\pi_{w \prime}=$ subjective probability of a trade war occurring. $\rho=$ coefficient of relative risk aversion.

ity and reliability of access rather than primarily improvement in amounts of access.

Results reported in table 3.6 relate to a different set of country objectives: tactical issues involving sequential formation of regional agreements. Here, model results evaluate the desirability, or otherwise, of first negotiating with a large country, or allowing the others to negotiate, and then joining the regional agreement later, the issue of interplay between localized and wider trade negotiations. ${ }^{15}$ For the CU case, model results suggest that there are substantial gains for both Canada and Mexico in being first in entering into an agreement with the United States. This is because the exclusion from the initial regional grouping increases the bargaining power of the larger group, and thus makes it more costly to enter later.

For the FTA case, there are benefits to Canada from following Mexico in the arrangement. This is because, as the results in table 3.6 show, the first entry of Canada into an FTA with the United States would entail a substantial loss for the United States; the side payment requested by the United States for a first entry by Canada would be accordingly large. By delaying entry, Canada can thus lower the cost of its admission into a North American FTA.

This result is opposite to that which is now frequently ascribed to NAFTA, which is thought to have detrimental effects on sequential entrants because of their limited ability to obtain new benefits, since their entry merely reapportions gains that have already accrued to other trading partners. The opposite

15. Perroni and Whalley (1994) first compute the Nash bargaining solution for the first-stage bilateral arrangement (assuming myopic behavior in the first-stage bargaining game) and use this outcome to define the disagreement point for the second-stage trilateral bargaining game. 
result for Mexico in this case is a reflection of the relative sizes of Canada and Mexico, and of the consequent reduced impact of a Mexico-U.S. free trade agreement in the retaliatory power of the United States.

In both the FTA and CU cases, the United States is better off by negotiating sequentially with its smaller partners than by engaging in a single threecountry trade negotiation. This result also serves to emphasize the dynamic instability of a regime in which large countries turn away from multilateralism, raising the risk of trade wars, increasing the size of the side payments they can extract, and further raising the incentives for a weakened commitment to multilateralism.

Like all analytical structures, this has limits in its application to the issues at hand. It gives no guide to the importance of strategic objectives in regional trade agreements, nor is it able to analyze the security offered to domestic policy reform. Nonetheless, its results do emphasize how particular country objectives in particular cases can be dominant (access guarantees for Canada in the Canada-U.S. agreement); and how, if the main objectives set for individual agreements are not kept firmly in mind, analyses of the impacts of agreements can be misleading.

\subsection{Concluding Remarks}

This paper stresses the need to recognize the varied objectives countries set for their involvement in regional trade agreements when evaluating the impacts of any particular agreement. It emphasizes how different regional trade arrangements are around the globe, reflecting the range of objectives that take countries into negotiations on these arrangements. Among those identified are the use of regional trade agreements to underpin domestic policy reforms (Mexico in NAFTA); the desire to achieve firmer market access with large trading partners (Canada in CUSTA); the link between trade agreements and strengthened security arrangements (EU); the use of agreements to strengthen collective bargaining power in multilateral trade negotiations (EU); the use of regional negotiations as a threat to driving multilateral negotiations forward (the United States in CUSTA, NAFTA). The paper closes by reporting previous model-based results that suggest that some objectives seem to quantitatively dominate others for particular agreements.

\section{References}

Anderson, K., and R. Blackhurst, eds. 1993. Regional Integration and the Global Trading System. Hemel Hempstead, England: Harvester Wheatsheaf.

Brooke, A., D. Kendrick, and A. Meeraus. 1988. GAMS: A User's Guide. Danvers, MA: Scientific Press. 
De La Torre, A., and M. R. Kelley. 1992. Regional Trade Agreements. Occasional Paper no. 93. Washington, DC: International Monetary Fund.

de Melo, J., and A. Panagariya, eds. 1993. The New Regionalism in Trade Policy. Washington, DC: World Bank.

Gatsios, K., and I. Karp. 1991. Delegation Games in Customs Unions. Review of Economic Studies 58:391-97.

Gorman, W. M. 1957. Tariffs, Retaliation, and the Elasticity of Demand for Imports. Review of Economic Studies 25:133-62.

Hamilton, B., and J. Whalley. 1983. Optimal Tariff Calculations in Alternative Trade Models and Some Possible Implications for Current World Trading Arrangements. Journal of International Economics 15:323-48.

Hamilton, C., and J. Whalley. 1996. The World Trading System after the Uruguay Round. Washington, DC: Institute for International Economics.

Haveman, J. D. 1992. Some Welfare Effects of Dynamic Customs Union Formation. Mimeo.

Johnson, H. G. 1953-54. Optimum Tariffs and Retaliation. Review of Economic Studies $21: 142-63$.

Kennan, J., and R. Riezman. 1990. Optimal Tariff Equilibria with Customs Unions. Canadian Journal of Economics 23:70-83.

Krugman, P. R. 1991. Is Bilateralism Bad? In E. Helpman and A. Razin, eds., International Trade and Trade Policy. Cambridge: MIT Press.

1993. Regionalism versus Multilateralism: Analytical Notes. In J. de Melo and A. Panagariya, eds., New Dimensions in Regional Integration. Cambridge: Cambridge University Press.

Mansur, A. H., and J. Whalley. 1984. Numerical Specifications of Applied General Equilibrium Models: Estimation, Calibration, and Data. In H. E. Scarf and J. B. Shoven, eds., Applied General Equilibrium Analysis. Cambridge: Cambridge University Press.

Markusen, J. R., and R. M. Wigle. 1989. Nash Equilibrium for the United States and Canada: The Roles of Country Size, Scale Economics, and Capital Mobility. Journal of Political Economy 97:368-86.

Perroni, Carlo, and John Whalley. 1994. The New Regionalism: Trade Liberalization or Insurance? NBER Working Paper no. 4626. Cambridge, MA: National Bureau of Economic Research, January.

Riezman, R. 1985. Customs Unions and the Core. Journal of International Economics 19:355-65.

Schott, J. J. 1989. Free Trade Areas and the U.S. Trade Policy. Washington, DC: Institute for International Economics.

Stoeckel, A., D. Pearce, and G. Banks. 1990. Western Trade Blocs: Game, Set, or Match for Asia-Pacific and the World Economy. Canberra: Centre for International Economics.

UN Conference on Trade and Development (UNCTAD). 1987. Guidebook for the GSTP: The Global System of Trade Preferences among Developing Countries: Origins, Dimensions, Negotiations, and Prospects. New York: UN Conference on Trade and Development.

Viner, J. 1950. The Customs Union Issue. Lancaster, PA: Carnegie Endowment for International Peace.

Whalley, J. 1993. Regional Trade Arrangements in North America: CUSTA and NAFTA. In J. de Melo and A. Panagariya, eds., New Dimensions in Regional Integration, 352-82. Washington, DC: World Bank.

World Trade Organization. Secretariat. 1995. Regionalism and the World Trading System. Geneva: World Trade Organization. 


\section{Comment Eric W. Bond}

John Whalley's paper provides a very nice survey of the different reasons why countries enter regional trading arrangements. These include the traditional welfare gains from preferential tariff reductions, the market-power benefits of forming a larger unit for tariff setting and bargaining, and strategic/political benefits from integrating markets and committing to preferential arrangements. Some of these reasons, such as the static welfare gains, have been extensively studied theoretically and empirically. Other reasons, such as the political and strategic benefits, are exceedingly difficult to quantify. Whalley points out that these differences in objectives are reflected in the heterogeneity in coverage of existing regional arrangements.

The novel aspect of the paper is his emphasis on the attempt by small countries to use a regional trade agreement to ensure market access to a largecountry market, and his attempt to quantify the magnitude of these gains. The Canada-U.S. Free Trade Agreement is the prototype for this type of regional arrangement, because one of Canada's primary negotiating objectives was to obtain exemption from U.S. anti-dumping and countervailing duty actions. Since these types of administrative actions account for a major portion of trade barriers in industrialized countries currently, the benefits from this type of market assurance may in many cases dominate any benefits obtained from reductions in tariff rates.

Whalley then uses a computable general equilibrium model to argue that the benefits from this form of market assurance may in fact be quite large. These gains stand in stark contrast to the static welfare effects of preferential arrangements, which typically yield very small numbers. The benefits that he calculates are based on the use of a regional trade arrangement as insurance against a global trade war. The simulation model assumes that there are two states of the world: normal trade relations in which GATT-negotiated tariffs apply and a trade war in which each country sets its optimal tariff. The simulations suggest that the small countries experience fairly significant losses during the trade war, because of their lack of market power, while some of the large countries actually gain. The formation of a regional trade agreement is assumed to commit the members to zero tariffs on intraunion trade in the event of a trade war. The small country obtains a higher payoff in the trade war when it is part of a regional agreement, because it obtains better terms of trade in dealing with the large country. Whalley's argument is that the small country should be willing to make transfers to the large country to receive this "insurance" against a trade war, and that the apparent willingness of small countries to make concessions to obtain regional agreements is evidence of the payment of this insurance premium. 'Perroni and Whalley (1994) report explicit calculations of the side payments for this model, where the formation of a regional trading ar-

Eric W. Bond is professor of economics at Pennsylvania State University.

1. Of course, the existence of transfers could merely reflect the supcrior threat point of the large country due to its market power. If the large country is better off in a trade war with the small 
rangement is derived from a two-stage game in which countries negotiate side payments in the first stage.

I have two reservations about this approach to capturing the benefits of market assurance. First, I don't think that the reason that Canada is worried about administered protection in the U.S. market is because of the possibility of a global trade war. A global trade war would result from a complete breakdown of multilateral trade agreements. Once these agreements break down, I see no reason why countries would limit themselves to "safeguards" type of protection. I would expect the trade war to be carried on through raising of tariff rates generally, so that insurance against the use of anti-dumping duties and safeguard actions per se would be of limited value. I find it more plausible to think of administered protection as arising from political pressure from special interests in the large-country market, with new protectionist measures coming from sector-specific shocks that lead to an increase in pressure for protection.

Ideally a trade agreement between countries would be a complete contract that would specify the tariff rates and/or transfers between countries for all possible realization of these shocks. ${ }^{2}$ Of course, such a contract would be costly to write because of the extremely large number of potential states. Here some of the insights from the literature on long-term contracting may be useful. In practice, parties to long-term contractual relationships do not fully specify all the terms of a contract, but instead include a negotiation process that will deal with circumstances that arise in the future. This introduces some flexibility into the process, while trying to minimize opportunism by the parties (Williamson 1979). I think that the dispute settlement procedures that were finally incorporated in the Canada-U.S. Free Trade Agreement can be interpreted as being part of a negotiation process in a long-term contractual relationship. This contractual approach to the bilateral trade agreement is similar in spirit to the Whalley argument, in the sense that it results from an attempt to complete a missing market or missing elements in global trade agreements. However, an attempt to quantify the gains from this type of approach would proceed quite differently.

The second point concerns the way in which the "insurance" benefits of regional arrangements are calculated in the computable general equilibrium model. In the event of a trade war, table 3.5 indicates that the United States has a gain of US\$52.5 billion and Canada has a loss of US\$100.2 billion, yielding a net loss of $\$ 47.7$ billion to the two countries in the trade-war state. An optimal insurance contract between the two (risk-averse) countries would involve a net transfer from the United States to Canada in the trade war, whose magnitude would depend on the countries' respective income levels and risk aversion. This could then be used to derive the benefits of this insurance agreement for

country than under free trade with that country, the small country must make transfers to the large country to induce it to sign a free trade agreement. Kowalczyk and Sjöström (1994) illustrate how side payments can be used to facilitate international negotiations.

2. For example, Feenstra and Lewis (1991) model such a contract when the realization of the shocks is private information of one of the countries. 
each country. One problem with this calculation is that the Nash equilibrium tariffs calculated for the trade war strike me as implausibly large - the SmootHawley tariffs look tiny compared with Nash equilibrium tariffs of 400-500 percent calculated for the United States. I suspect that the low elasticity assumptions that generate these tariffs bias upward the benefits from the calculation of the benefits of an optimal insurance contract. A second problem is that the calculation of the benefits from the formation of a preferential trading arrangement qua insurance contract will involve both insurance and marketpower effects. A customs union between the United States and Canada results in the two countries' obtaining a net gain of US $\$ 25.5$ billion in the trade-war state. The additional market power obtained by the two countries when they are setting external tariffs jointly results in a net gain to the two countries in the trade-war state, so that the customs union would clearly be desirable for the two countries even if the two countries were risk neutral (or had an optimal insurance contract in place). A free trade agreement provides similar, although smaller, net gains to the two countries in the trade-war state.

Another question that is of importance to the trade war/insurance argument is why the trade war results in a breakdown of multilateral trade agreements, but not of regional agreements. Implicit in this argument is a greater degree of commitment power on the part of countries in regional trade agreements, which allows them to write binding contracts to free intraregional trade. ${ }^{3}$ This seems a reasonable assumption for the European Union and the CanadaU.S. agreement. Given the number of examples of unsuccessful regional agreements, however, I would argue that GATT has had a more successful and enduring impact on trade relations than the median regional agreement. Thus, the potential for new regional agreements with the ability to commit to insure against trade wars may be relatively limited. The source of this ability to commit, which may be related to some of the strategic and political reasons cited by Whalley, is an area worthy of further analysis.

In summary, the variety of motives that lead countries to form regional agreements suggests that evaluation of whether the move toward more regionalism is a good thing requires a greater understanding of the implications of these various explanations. Perroni and Whalley's market assurance idea is an intriguing explanation of the role of regional agreements, and I think that this paper makes a useful first step in developing a formal model of this notion.

3. This asymmetry between commitment power is emphasized in Bagwell and Staiger (1997). Bond and Syropoulos (1995), and Bond, Syropoulos. and Winters (1995). In these papers, countries are assumed to be able to write binding agreements with regional trading partners. but not with nonmember countries. Multilateral trade agreements are treated as a repeated game. in which the threat of a global trade war is used to support trade policies that are more liberal than those in the trade-war equilibrium. There is no insurance element to agreements in these models, because trade wars never occur. However, these models are capable of addressing how the formation of regional agreements affects the multilateral agreement. This issue is not addressed in the Perroni and Whalley approach. where the normal tariff rates and the probability of a trade war are taken as exogenously given. 


\section{References}

Bagwell, Kyle, and Robert Staiger. 1997. Multilateral Tariff Cooperation during the Formation of Regional Free Trade Areas. International Economic Review 38:29l-319.

Bond, Eric, and Costas Syropoulos. 1996. Trading Blocs and the Sustainability of InterRegional Cooperation. In M. Canzoneri, W. J. Ethier, and V. Grilli, eds., The New Transatlantic Economy. London: Cambridge University Press.

Bond, Eric, Costas Syropoulos, and Alan Winters. 1995. Deepening of Regional Integration and Multilateral Trade Agreements. Pennsylvania State University working paper.

Feenstra, Robert, and Tracy Lewis. 1991. Negotiated Trade Restrictions with Private Political Pressure. Quarterly Journal of Economics 106:1287-1307.

Kowalczyk, Carsten, and Tomas Sjöström. 1994. Bringing GATT into the Core. Economica 61:301-17.

Perroni, Carlo, and John Whalley. 1994. The New Regionalism: Trade Liberalization or Insurance? NBER Working Paper no. 4626. Cambridge, MA: National Bureau of Economic Research, January.

Williamson, Oliver. 1979. Transaction-Cost Economics: The Governance of Contractual Relations. Journal of Law and Economics 22:233-62.

\section{Comment Dani Rodrik}

This is essentially two papers, one of which is a useful discussion and categorization of reasons countries choose to enter regional arrangements, and the other a summary of the author's earlier work with Perroni on a CGE model that focuses on one of these motives (insurance). I found the first paper to be extremely well done, and I have nothing to add to it. I will focus my comments on the second paper.

The insurance idea that forms the core of the analytics in this paper is quite appealing and plausible. The message is that countries want regional arrangements in no small part because they would like to buy insurance against future protection. The implication is that evaluating the gains from regional integration by taking as the relevant counterfactual the current situation will yield a serious underestimate. This is an important point.

How do we think about the insurance motive? Whalley proceeds as follows. First, he constructs a world CGE model of trade. Second, he simulates the Nash equilibrium tariffs under various assumptions about who enters into regional arrangements with whom. A key assumption here is that trade wars (i.e., a Nash equilibrium) occur only among blocs, not within groups of countries that have entered into a regional arrangement with each other. Countries within a bloc are assumed to always maintain zero tariffs vis-à-vis each other. Third, 
he compares the benchmark (1986) situation to these various outcomes, focusing on gains to being inside a regional arrangement during a global trade war.

One can list here the usual quibbles about CGE models. Since these are well known, I'd rather skip the quibbles and move on to my main reactions. My main methodological quarrel with the paper is that the setup cannot adequately deal with the question that motivates it. Since the theme is "insurance," one expects the framework to be about risk and uncertainty. But in fact, the model does not have uncertainty explicitly built into it, and therefore cannot address issues of risk and insurance. And for that reason, the model does not allow for a direct quantitative assessment of the importance of the insurance motive. My main substantive reaction is that, partly as a consequence, the paper probably overstates the quantitative significance of the insurance motive. Let me list here my three reasons for believing so, as these will also highlight the methodological issues.

First, the model generates Nash-equilibrium tariffs that are implausibly high: around 500 percent for the United States and 900 percent for the EU. These result in huge welfare losses for small countries that remain outside blocs. Canada, for example, loses a quarter of its GNP, and other Western Europe loses a third. What drives these results are two things: (1) the trade elasticities used in the model are low; and (2) governments are assumed to be driven only by the terms-of-trade motive when playing Nash. The latter assumption is commonplace in models of this sort, but is probably unrealistic. (Think, for example, of how governments often play the game of competitive devaluation, despite the associated terms-of-trade losses.) This is not to say that a global trade war of such proportions should be regarded as a zero-probability event. But surely it is a low-probability event, and the associated "insurance" gains have to be scaled down according to this low probability of occurrence.

Second, and leaving aside the question of what global trade war would entail, it is implausible to think that countries like Canada and Mexico really thought they were buying insurance against a truly global trade war. It is likely that they had a much more limited insurance motive: to prevent localized, product-specific surges in protectionism through safeguard or anti-dumping (AD) action in the United States. Indeed, the initial discussion in the paper on what type of insurance these countries were really after seems more accurate (and considerably more limited). Incidentally, one wonders whether there is any evidence that the insurance policy is paying back. For example, has U.S. trade action against Canada been reduced after 1992? In any case, the anticipated gains from this kind of insurance would be considerably smaller.

Third, the discussion does not take into account that the formation of regional arrangements may itself increase the likelihood of "trade wars." In other words, what is being insured against may well be a situation that becomes more likely as more countries buy insurance. For example, when Canada and Mexico insure themselves against AD action in the U.S. market, this probably increases the protectionist pressures felt by other exporting countries. It is be- 
cause of this kind of spillover that the incentive to join a regional arrangement increases with the number of countries already in. This would suggest that there is a wedge between what may be individually rational for a country (go and buy insurance) and what is globally rational. Correspondingly, in equilibrium the value of insurance is likely to be lower (than anticipated) for all concerned.

Let me end with two facts that this paper made me aware of, which need further thought. First, with the exception of the Israel-U.S. Free Trade Agreement, all regional arrangements are indeed regional, that is, they involve geographically contiguous countries. That's why we use the term "regional integration" in the first place. But going back to Whalley's discussion of the reasons why countries join such arrangements, very few of the things that we normally focus on have any geographical content at all. I am not sure what the implication of this is, but it does suggest to me that our discussions often leave an important dimension out. Second, it appears that most GATT/WTO members are now members of at least one regional arrangement also. This is a striking fact. It suggests to me that governments clearly regard regional and multilateral approaches as complementary. So we should stop thinking of these as mutually exclusive choices. 
This Page Intentionally Left Blank 